\title{
Kosovo's ethnic divide blights UN science rebuilding plans
}

Quirin Schiermeier, Munich

Attempts by the United Nations (UN) to reconstruct science and education in Kosovo may be ending prematurely, according to UN officials working in the area.

Ethnic tension and corruption in the region mean that it is too early to hand over responsibility to the local self-administration, says Michael Daxner, who sets science and education policy at the United Nations Interim Administration Mission in Kosovo. But with some powers already transferred to the new administration, which Daxner claims is discriminating against the country's Serb minority, he says there is little more he can do, and last week he announced plans to leave his post by the end of the month.

The interim UN administration was set up in June 1999 after NATO bombing forced former Serbian president Slobodan Milosevic to agree to a peace plan hammered out by the G8 group of leading industrialized nations. Education and science were seen as key elements in the bid to rebuild the country's infrastructure and bring reconciliation between the Albanian-speaking majority and the small remaining Serb minority.

When Daxner and his colleagues began work in spring 2000, they found many schools and laboratories destroyed, and a climate of open violence. "Our main concern in the emergency period after the war was really to keep people from killing one another," he says.

The University of Pristina, then the region's only university, also bore scars from the recent conflict. Milosevic had eradicated the Albanian language from the formerly bilingual institution, and many Albanianspeaking professors had been expelled.

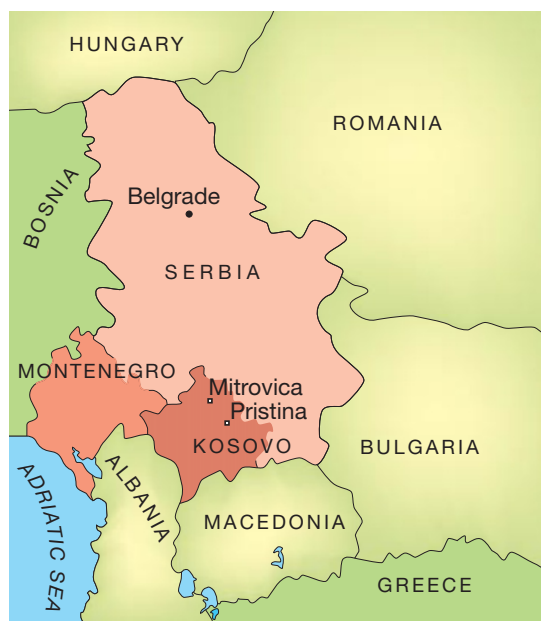

Language barrier: Kosovo's new university in Mitrovica receives funding from Serbia.
"When our premises were occupied by Serbian staff, some of us continued teaching in private houses, while others went to labs in the Albanian capital Tirana, or to Turkey or Germany," recalls Rexhep Ismajli, a linguist and secretary-general of the Academy of Science and Art in Kosovo.

Thanks to aid of around 120 million euros (US\$116 million), roughly half of it donated by the UN, a makeshift education system has been set up. Primary-school education is in place throughout much of the region. And the University of Pristina, now one of two higher-education institutes in Kosovo, hosts some 25,000 students. But equipment and Internet connections are scarce, and there are few opportunities for scientific research.

Since the war, the university has also been dominated by an anti-Serbian ideology. Serbian students can enrol on courses, but security issues and discrimination make it impossible for them to study there. "Kosovo's Albanian-speaking majority is still extremely prejudiced against the Serbian minority, and the regional self-administration tends to cement the ethnic divide," says Daxner, a sociologist and former president of the University of Oldenburg in Germany.

Attempts by the UN interim administration to assist a new Serbian-language university in Mitrovica, north of Pristina, have also run into difficulties. The fledgling institution is being backed by the government in neighbouring Serbia, which is providing funding and staff. But many Kosovans view the idea as unwanted political interference. "We are not denying the right of Serbs to get higher education, but any mix of competencies between Pristina and Belgrade has the potential for conflict," says Ismajli. "Some people at the interim administration have the biased idea that Kosovo is a wasteland, lacking academic tradition. We are grateful for the UN's help in many ways, but there are many things which I believe we could have done better alone.'

Daxner says the UN policy of handing over power to the local administration, the implementation of which began earlier this year, meant that he could make no headway on the Mitrovica university. He raised these and other problems, including nepotism, in a report presented to the Kosovo Education Conference, held in Pristina this June by the Organisation for Economic Co-operation and Development. But with the Kosovo authorities denying his charges, and further transfers of power planned, Daxner says there is little scope for him to change the situation.
Second round of gene sequencing goes down to the farm

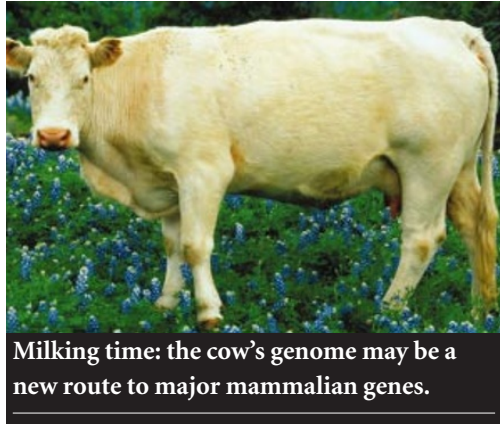

Kendall Powell, Washington

The cow, dog and a single-celled genetic powerhouse called Oxytricha trifallax are the latest organisms to be named as high priorities for genome sequencing by the US National Human Genome Research Institute in Bethesda, Maryland.

On 11 September, the institute announced its second round of sequencing priorities, having asked researchers to submit 'white papers' making the case for their favourite organisms. The newcomers join the chicken, chimpanzee, honeybee, the sea urchin Strongylocentrotus purpuratus, the protozoan Tetrahymena thermophila and 15 species of fungi (see Nature 417 , 473-474; 2002).

Steven Kappes, director of the US Department of Agriculture's Meat Animal Research Center in Clay Center, Nebraska, says that the cow offers "another avenue" to identify important mammalian genes. Whereas biomedical researchers use lab animals primarily as models of human disease, agricultural scientists tend to focus on normal processes such as muscle development and reproduction.

Man's best friend, however, shares many of our maladies. The dog's supporters touted the animal as a model for various diseases, including cancer, heart disease and deafness.

The protozoan Oxytricha, meanwhile, is an evolutionary oddity. It seems to package each of its 30,000 genes into a tiny individual chromosome. Each time it divides, it spits out accumulated 'junk' DNA. As a result, Oxytricha crams about the same number of genes as the mouse into a genome some 60 times smaller.

Oxytricha had previously been ranked as a moderate priority, alongside the rhesus macaque - to the bitter disappointment of researchers who use this monkey in biomedical research. The macaque genome proposal will be resubmitted in October. 